\title{
Sosyal Bilgiler Öğretmenlerinin Tarih Konularının Öğretimine Yönelik Görüşleri
}

\section{Views of Social Studies Teachers on History Education}

\section{Meral Metin Göksu ${ }^{1}$,}

\begin{tabular}{|c|c|}
\hline Anahtar Kelimeler & Öz \\
\hline öğretmen & Tarih konularının anlatımında öğrencide problem çözme becerisinin geliştirilmesi, empati yapması ve yaratıcı düşünme gibi \\
\hline sosyal bilgiler & kavramlar kullanılarak tarih konuları ezber olmaktan çıkartılmaya çalışılmaktadır. Tarih öğretiminde amaçlanan hedeflere \\
\hline sorunlar & kullanacağı farklı yöntem ve tekniklerle öğrencilerin yaratıcı, sorgulayıcı ve eleştirel düşünme gibi üst düzey zihinsel becerilerini \\
\hline tarih & $\begin{array}{l}\text { kullanmaya özen göstermesi gerekmektedir. Bunu yaparken de öğrencinin dikkatini derse çekecek, öğrenciyi motive edecek ve } \\
\text { dersi eğlenceli hale getirecek yöntem ve teknikler kullanılmaktadır. Bu çalıșmada Sosyal Bilgiler dersinde tarih konularının }\end{array}$ \\
\hline Keywords & öğretimi esnasında Sosyal Bilgiler öğretmenlerin yaşadığı sorunlar ve çözüm önerilerini belirlemek amaç edinmiştir. Çalışmanın \\
\hline teacher & odak grubunu Kars ili merkez ortaokullarında çalışan 13 Sosyal Bilgiler öğretmeni oluşturmuştur. Nitel yöntemin kullanıldığı bu \\
\hline social studies & ilişki kurabilmek için analiz sırasında ortaya çıkan açıklayıcı, çıkarımsal kodlar kullanılmıştır. Sosyal Bilgiler öğretmenleri tarih \\
\hline problems & konularını anlatırken ders saatinin yetersizliği, ders kitabının yüzeysel olması, öğrencinin dersi ezber bir ders olarak görmesi, \\
\hline history & $\begin{array}{l}\text { dersi sıkıcı bulması ve bu dersten sadece yüksek not almak istemesinden dolayı sorun yaşadıklarını ifade etmişlerdir. Bunun } \\
\text { yanı sıra tarih dersine karşı önyargılar ve tarih konularına ilginin az olması da belirtilmiştir. Yapılan çalışmada öğrenciler çeşitli }\end{array}$ \\
\hline Başvuru Tarihi/Received & nedenlerden dolayı tarih konularına yeteri kadar ilgi göstermediği anlaşılmıştır. \\
\hline 04.11 .2019 & Abstract \\
\hline Kabul Tarihi /Accepted & History teaching has tried to go beyond the traditional fashion by using concepts such as developing problem-solving skills, \\
\hline 21.07.2020 & $\begin{array}{l}\text { empathy and the creative thinking of the students. It is necessary to increase the quality of history teaching in order to achieve } \\
\text { the aims of history education. With different methods and techniques that are to be used by the social studies teachers during } \\
\text { the history lessons, students should pay attention to the use of their high-level cognitive skills such as creative, skeptical, and } \\
\text { critical thinking. While doing this, methods and techniques will be deployed that are used to draw the student's attention to } \\
\text { the lesson, motivate the student, and make the lesson enjoyable. The purpose of this study is to determine the problems } \\
\text { experienced by social studies teachers and the solutions they suggest on teaching history subjects in their Social Sciences } \\
\text { lessons. The focus group consisted of } 13 \text { social studies teachers working in the central provinces of Kars city. Researchers used } \\
\text { semi-structured interviews to collect data, and used qualitative analysis, explanatory and deductive codes to explore emerging } \\
\text { patterns in the data. Social studies teachers have expressed that they have problems in teaching history due to the insufficiency } \\
\text { of the class hours, the superficial schoolbooks, students learning in the fashion of parrots, students finding history lessons } \\
\text { boring and only wanting to get high grades from this lesson. In addition, it has been stated that there are prejudices against } \\
\text { history classes and there is a low interest in the history subjects. In the study, it has been understood that the students do not } \\
\text { show enough interest in history subjects for various reasons. }\end{array}$ \\
\hline
\end{tabular}

\footnotetext{
${ }^{1}$ Sorumlu Yazar, Kafkas Üniversitesi, Dede Korkut Eğitim Fakültesi, Türkçe ve Sosyal Bilgiler Eğitimi Bölümü, Sosyal Bilgiler Eğitimi, Kars, TÜRKiYE; https://orcid.org/0000-0002-6858-7544
}

Alıntı/Citation: Göksu, M. M. (2020). Sosyal bilgiler öğretmenlerinin tarih konularının öğretimine yönelik görüşleri. Kastamonu Education Journal, 28(5), 19461955. doi: $10.24106 /$ kefdergi.4039 


\section{Extended Abstract}

\section{Introduction}

History teaching has tried to go beyond the traditional fashion by using concepts such as developing problem-solving skills, empathy and the creative thinking of the students. It is necessary to increase the quality of history teaching in order to achieve the aims of history education. History education in Turkey has become the focus of criticism as being insufficient in terms of achieving its aims (Avcl Akçalı \& Aslan, 2016). With different methods and techniques that are to be used by the social studies teachers during the history lessons, students should pay attention to the use of their high-level cognitive skills such as creative, skeptical, and critical thinking. While doing this, methods and techniques will be deployed that are used to draw the student's attention to the lesson, motivate the student, and make the lesson enjoyable. The study that has been made is important in terms of expressing the views of Social studies teachers on teaching history subjects.

Purpose: The purpose of this study is to determine the problems experienced by social studies teachers and the solutions they suggest on teaching history subjects in their Social studies lessons. Accordingly, researchers have looked for answers to the following questions: In teaching history subjects;

- What are the views of social studies teachers on the sufficiency of learning outcomes in the 2018 social studies curriculum?

- What are the methods used by the social studies teachers?

- What are the thoughts of social studies teachers on self-sufficiency levels?

- What kinds of problems are experienced by social studies teachers?

- What are the suggested solutions for the problems experienced by social studies teachers?

\section{Method}

Study model: In this study, the qualitative method has been used in which the researcher is active in the process of gathering information and the perceptions and events are presented in a realistic and holistic perspective, in either an unwritten or verbal form (i̇slamoğlu, 2009; Robson, 2015; Yıldırım and Şimşek, 2008).

Study group: The study group has been formed according to the appropriate case study group technique, depending on the selection of the person or groups to be surveyed conveniently (Sönmez and Alacapınar, 2014). The study group consists of 13 social studies teachers in total, 7 women and 6 men.

Data collection instruments and data analysis: In order to collect data in accordance with the purpose of the study, the interview technique, providing in-depth information about the research subject (Büyüköztürk et al, 2010), has been used. Interviews with teachers lasted 10-15 minutes. The obtained data was collected and analyzed. Descriptive and inferential codes generated during the analysis was used to explain and relate the collected qualitative data. In order to increase the reliability, the interview analyze was coded separately by 2 different experts (social studies education specialist). The reliability of the study has been determined as $86 \%$. The codes and findings obtained from the study have been directly quoted without the interpretation of the researcher. The teachers have been coded as T1, T2, T3, T4, etc.

\section{Findings}

Views on the sufficiency of learning outcomes in the social sciences curriculum: Social studies teachers have stated that the learning outcomes related to history subjects in the social studies curriculum are not sufficient, that the class hours in the program should be increased, or the learning outcomes should be reduced. The examples of the views of Social studies teachers are as follow:

"No, they are not sufficient. It is not appropriate to storify in the book what two people experience. It is also a contradiction to ask questions to test the knowledge while giving stories..." (T1)

Views of social studies teachers on the methods and techniques they use while giving history classes: While most of the Social studies teachers have stated that they use question and answer teaching method and direct instruction techniques in their lessons, many of them use drama. Also it has been seen that the number of teachers using maps, using smart board, holding competitions, making the students take notes, reviving historical events, and holding discussions are very close to each other. Quotes from the teachers' views are presented below:

"Due to the shortage of time, we give the lessons by using direct instruction and question-answer techniques and making students take notes." (T2)

Self-sufficiency perceptions of social studies teachers on history education: Most of the Social studies teachers have expressed that they consider themselves sufficient in teaching history. The followings are the quotes of the teachers' views:

"Yes but I can improve myself a little more in terms of knowledge." (T8)

Problems of social studies teachers in teaching history: Most of the Social studies teachers have stated that they have problems because of insufficient class hours, superficial schoolbooks, students learning in the fashion of parrots, students finding history lessons boring and only wanting to get high grades from this lesson. Besides, prejudices against history lessons and low interest in history subjects have also been mentioned as other problems. The followings are the quotes from the teacher views:

"School books are too superficial, they are not sufficient in history education." (T10)

Solution suggestions on the problems of social studies teachers in teaching history: The Social studies teachers have expressed that the class hours should be increased in history education, the content of the lesson should be prepared considering the readiness of the students and visuals should be included more in schoolbooks. The following s are the quotes from the teacher views:

"The content of the lessons should be prepared considering the readiness of the students and the class hours should be increased." (T3)

\section{Result and Discussion}

In the teaching of history subjects, the teachers have stated that they do not consider the curriculum adequate and that the program should be prepared considering the learning outcomes or the class hours. Similar results can be found in different studies that have been made. Most of the social studies teachers use the question-answer and direct instruction technique when they give history lessons while some of the teachers 
use drama. It has also been observed that the number of teachers using maps, using smart boards, holding competitions, making students take notes, reviving historical events and holding discussions are close to each other. According to the results obtained from the study, it can be said that most of the teachers use direct instruction and question-answer method. They have remarked that insufficient class hours is the reason for using this method. Most of the Social Studies teachers have expressed that they consider themselves adequate in teaching history because they had a good education during their undergraduate years. Social studies teachers have expressed that they have problems in teaching history due to the insufficiency of the class hours, the superficial schoolbooks, students learning in the fashion of parrots, students finding history lessons boring and only wanting to get high grades from this lesson. In addition, it has been stated that there are prejudices against history classes and there is a low interest in the history subjects. In the study, it has been understood that the students do not show enough interest in history subjects for various reasons. Social studies teachers have remarked that lesson hours should be increased, the student readiness in the content of the lesson should be taken into account and the visuals should be included more in the schoolbooks.

\section{GíRiş}

Sosyal Bilgiler dersi, bireyin kendini tanımasını ve toplumsal bir kimlik kazanmasını sağlamak için içeriğinde birçok bilgi, beceri ve değeri barındırmaktadır. Bu ders bir yandan öğrencileri yaşama hazırlarken diğer yandan öğrencilerin toplumun etkin bir üyesi olmasına yardımcı olmaktadır. Sosyal Bilgiler dersi tarih, coğrafya, sosyoloji, ekonomi, antropoloji, felsefe, psikoloji, siyaset bilimi ve hukuk gibi sosyal bilimler ile insan hakları, yurttaşlık ve demokrasi konuları gibi birçok disiplini bünyesinde toplamıştır (MEB, 2018). Sosyal Bilgiler dersi farklı disiplindeki bilgilerin etkili ve anlaşılır bir şekilde bir araya gelmesiyle oluşmuştur (Turna ve Bolat, 2015). Sosyal Bilgiler dersini oluşturan farklı disiplinler içinde tarih konuları ayrı bir yere sahiptir. Çünkü tarih konuları öğretilirken öğrencilerin geçmişi sorgulaması, gelecek hakkında öngörüde bulunması ve onlara milli kimlik kazandırıp kültürel mirasın gelecek nesillere aktarılmasında önemli bir yer tutmaktadır (Dilek, 2002; Ulusoy, 2009). Tarih öğretimiyle insani değerlerin tümüne saygı duyan, sorumluluk sahibi, geçmiş ve gelecek arasında köprü kurabilen, araştırmayı benimseyen, bilinçli, demokratik değerleri bilen ve milli kültürünü benimseyip yaşatan yeni nesiller (Karabağ, 2011; Yıldız, 2002) yetiştirmek amaçlanmıştır. Dahası bireylere üst düzey düşünme becerilerini kazandırarak, çağdaş problemleri çözmede yardımcı olmaktır (Dinç, 2006). Bundan dolayı tarih sosyal bilimlerin temel disiplini oluşturmaktadır (Er ve Bayındır, 2015). Öğrencilere tarih bilinci kazandırmak için öncelikle tarihin ne olduğu ve niçin öğretilmesi gerektiği bilinmelidir. Çünkü günümüz bireyleri, geçmişini ne kadar iyi tanırsa geleceğe o kadar güvenle bakabilir. Bundan dolayı tarih konularının öğretiminde farklı yaklaşımların kullanılması bu dersi tekdüzelikten kurtararak konuların daha eğlenceli ve etkin şekilde işlenmesine olanak sağlamaktadır (Öner, 2015).

Sosyal Bilgiler dersinde tarih konularının öğretiminde, öğrencinin problem çözme becerisini geliştirilmesi, empati yapması ve yaratıcı düşünme gibi kavramları kullanılarak tarih konuları ezber olmaktan çıkartılmaya çalışılmaktadır. Tarih öğretiminde amaçlanan hedeflere ulaşılabilmek için tarih öğretiminin niteliğini artırmak gerekmektedir. Çünkü Türkiye'de verilen tarih eğitimi hedeflere ulaşmada noktasında eksik kalarak tarih eğitimine yönelik yapılan eleştirilerin odak noktası haline gelmiştir (Avcı Akçalı ve Aslan, 2016). Tarih öğretiminde eleştirilen noktalardan birisi de kullanılan yöntem ve teknik olmuştur. Sosyal Bilgiler öğretmenleri tarih konularını öğretirken kullanacağı farklı yöntem/tekniklerle öğrencilerin yaratıcı, sorgulayıcı ve eleştirel düşünme gibi üst düzey zihinsel becerilerini kullanmasına ortam hazırlaması gerekmektedir. Öğretmen bunu yaparken öğrencinin dikkatini derse çekecek, öğrenciyi motive edecek ve dersi eğlenceli hale getirecek farklı yöntem/teknik kullanmalıdır. Kullanılan farklı yöntem ve tekniklerle, öğrenciler Sosyal Bilgiler dersinde tarih konularına karşı daha ilgili olacaktır.

Ülkemizde yapılan çalışmalara bakıldığında tarih öğretiminde farklı yöntem ve teknikler kullanılmaktadır. Özellikle de Kaymakcı (2017) tarafından yapılan çalışmada, ülkemizde tarih öğretim alanında yapılan çalışmalarda yapılandırmacı yaklaşım, araştırmainceleme yoluyla öğretim stratejisi, tarih derslerinde kullanılabilecek öğrenci merkezli yöntemler, proje tabanlı öğrenme, tartışma yöntemi, gezi gözlem ve inceleme yöntemi, metafor ve analojiler, tarihsel canlandırma, NLP (Sinir Dili Programlama-Neuro Linguistic Programing) eğitimi tekniklerinin uygulandığı belirtilmiştir. Kullanılan farklı yöntem ve tekniklerin sayesinde öğrencilerin derse karşı ilgisinin arttığı ve dersi sıkıcı olmaktan çıkardığı bilinmektedir. Fakat benzer çalışmalara bakıldığında Sosyal Bilgiler dersinde tarih konuları öğretilirken ezbere dayalı düz anlatım yoluyla tarih öğretimi gerçekleştirildiği görülmektedir (Akbaba, 2008; Güngör, 2019). Tarih konularının ezbere dayalı bir eğitimle verilmesine gerekçe olarak da, öğrencinin dersten sıkılması, derse olan ilginin azalması ve derse ayrılan sürenin yetersiz (Pekuslu, 2019; Topçu, 2016, Yılmaz ve Tepebaş, 2011) olması gösterilmektedir. Bu sebeple Sosyal Bilgiler dersinde tarih konularının öğretiminde farklı yöntem ve teknik kullanılması gerekmektedir. Öğretim yöntemleri seçilirken de öğretmenin yöntem konusundaki becerisi, içeriğin yapısı, öğrencilerin hazırbulunuşluk düzeyi, ulaşılacak hedefler, öğrenci sayısı, derslik ve büyüklüğü dikkate alınmalıdır. Sosyal Bilgiler öğretiminde daha çok düz anlatım, problem çözme, örnek olay incelemesi ve soru-cevap (Gökalp, 2016) gibi yöntemler aktif olarak kullanılmaktadır. Bunun yanı sıra drama tekniği, canlandırma, beyin fırtınası, anlatım, gezi ve eğitsel oyun gibi teknikler de kullanılmaktadır. Fakat anlatım ve soru-yanıt tekniği bazı kaynaklarda yöntem olarak belirtilmektedir (Yıldızlar, 2013).

Sosyal Bilgiler öğretmenlerinin, Sosyal Bilgiler öğretiminde yaşadığı sorunlar, kullandıkları yöntemler ve programda karşılaşılan sorunlara dair alan yazında yapılan araştırmalar mevcuttur. Bunlardan bazıları şunlardır. Arslantaş (2006) ve Atbaşı (2007) tarafından yapılan iki farklı çalışmada SBÖP’nin çok kapsamlı olduğu ve öğrencilerin kavrama seviyelerinin üzerinde soyutluk taşıdığını vurgulamışlardır. Aynı zamanda programın yoğunluğundan dolayı bazı konulara çok ayrıntılı (Kuş ve Çelikkaya, 2010) yer verildiği belirtilmiştir. Tonga (2017) çalışmasını Sosyal Bilgiler eğitiminde karşılaşılan sorunlar, Sosyal Bilgiler öğretmenlik eğitimi, hayat boyu eğitim boyutu, öğretmen adaylarının motivasyon sorunu, Sosyal Bilgiler eğitimi müfredat boyutu ve iyi insan, iyi vatandaş hedefinin belirsizliği olarak kategorilere ayırarak incelemiş ve bunlara yönelik çözüm önerisi sunmuştur. Akgül'ün (2006), sınıf öğretmenlerinin Sosyal Bilgiler öğretiminde kullandıkları yöntemleri ve karşılaştıkları sorunları tespit etmeyi amaçlayan 
çalışmasında, öğretmenlerin 'gözlem gezisi, tarihsel empati, ekiple öğretim' gibi yapılandırmacı yaklaşıma dayalı öğretim yöntemlerini süre yetersizliği, araç-gereç yetersizliği gibi çeşitli nedenlerden dolayı daha az kullandıkları belirtilmiştir. Has (2019) tarafından yapılan çalışmada sınıf öğretmenlerinin Sosyal Bilgiler dersinde kullandıkları yöntem ve tekniklere değinilmiş, Sosyal Bilgiler dersinde yöntem çeşitliliğine çoğunlukla yer verilmediği, çoğunlukla soru-cevap ve anlatım yöntemlerini kullandıkları, aktif öğretim yöntem ve teknikerini ise çeşitli nedenlerden dolayı kullanmadıkları sonucuna ulaşılmıştır

Tarih öğretiminde yaşanan sorunlara dair alan yazında yapılan çalışmalardan bazıları şunlardır. Sadık Yılmaz (2017) tarafından yapılan çalışmada tarih öğretiminde yaşanan sorunlar, ders kitapları ve müfredattan kaynaklı, ders materyallerinin eksikliğinden kaynaklı, tarih öğretmenlerinin eğitimdeki eksikliğinden kaynaklı, tarihi mekânların kullanılmamasından kaynaklı, yöntem ve teknikten kaynaklı sorunlar olarak ayrılmıştır ve bunlara yönelik sorunlar tespit edilmiştir. Yıldız (2003) çalışmasında tarih öğretiminin sorunları, tarih ders kitaplarının niteliğinden kaynaklanan problemler ve tarih öğretim yöntemlerinden kaynaklanan problemler olarak ele almıştır. Topçu (2016) çalışmasında Sosyal Bilgiler öğretmenlerinin bakış açılarına göre ortaokulda tarih öğretiminin mevcut durumu ve tarih öğretiminde yaşanan yapısal kaynaklı sorunların tespiti ve bu sorunlara yönelik çözüm önerileri sunmuştur. Bal (2011) tarafından yapılan çalışmada ise tarih öğretiminde yaşanan sorunlar müfredat kaynaklı, yöntem ve teknikler kaynaklı, tarih biliminin doğası ve dersin imajı kaynaklı ve genel eğitim sisteminden kaynaklanan sorunlarınlar olarak ayrılış ve bunların çözüm önerileri dile getirilmiştir.

İlgili literatür tarandığında Sosyal Bilgiler dersi tarih konularının öğretiminde yaşanan sorunların belirlendiği, Sosyal Bilgiler öğretmenlerinin kullandıkları yöntemleri belirlemeye yönelik araştırmaların yapıldığı görülmektedir. Bu bağlamda Sosyal Bilgiler öğretmenlerinin görüşleri doğrultusunda Sosyal Bilgiler dersi öğretim programında yer alan kazanımların yeterliği, öğretmenlerin kullandıkları yöntemler, Sosyal Bilgiler dersinde tarih konularının öğretiminde öğretmenlerin öz yeterlik düzeyleri ve yaşadıkları sorunların tespit edilmesinin literatüre katkı sağlayacağı düşünülmektedir.

\section{Amaç}

Yapılan çalışmada Sosyal Bilgiler dersinde tarih konularının öğretimi esnasında Sosyal Bilgiler öğretmenlerin yaşadığı sıkıntılar ve çözüm önerilerini belirlemek amaç edinmiştir. Bu doğrultuda aşağıda verilen sorulara yanıt aranmıştır:

Sosyal Bilgiler öğretmenlerinin, tarih konularının öğretiminde;

- 2018 Sosyal Bilgiler dersi öğretim programında (SBÖP) yer alan kazanımların yeterliğine yönelik görüşleri nelerdir?

- Kullandıkları yöntem nelerdir?

- Öz yeterlik düzeyleri konusunda düşünceleri nelerdir?

- Yaşadıkları sorunlar nelerdir?

- Yaşadıkları sorunlara yönelik çözüm öneri nelerdir?

\section{YÖNTEM}

\section{Araştırmanın Modeli}

Çalışmada, araştırmacının bilgi toplama sürecinde aktif olarak yer aldığı, algı ve olayların doğal ortamında gerçekçi bir biçimde ve bütüncül bir bakış açısıyla, yazılı olmayan ya da sözlü bir formda ortaya konduğu (İslamoğlu, 2009; Robson, 2015; Yıldırım ve Şimşek, 2008) nitel yöntem kullanılmıştır.

\section{Çalışma Grubu}

Araştırmanın çalışma grubu, amaçlı örneklemenin, üzerinde kolaylıkla araştırma yapılacak kişi ve grupların seçilmesine dayalı (Sönmez ve Alacapınar, 2014) uygun durum çalışma grubu tekniğine göre oluşturulmuştur. 2018-2019 eğitim-öğretim yılı 1. dönem Kars il merkezinde 9 ortaokulda görev yapan toplam 13 Sosyal Bilgiler öğretmeni oluşturmaktadır. Çalışma gurubunu oluşturan Sosyal Bilgiler öğretmenlerine ait bilgiler aşağıdaki tabloda yer almaktadır.

Tablo 1. Sosyal bilgiler öğretmenlerine ait demografik özellikler

\begin{tabular}{|c|c|c|}
\hline & & Katılımcı sayısı \\
\hline \multirow[t]{2}{*}{ Cinsiyet } & Kadın & 7 \\
\hline & Erkek & 6 \\
\hline \multirow{5}{*}{ Yaş } & $25-30$ yaş & 3 \\
\hline & $31-35$ yaş & 2 \\
\hline & $36-40$ yaş & 4 \\
\hline & $41-45$ yaş & 2 \\
\hline & $45-50$ yaş & 2 \\
\hline \multirow{5}{*}{ Mesleki deneyim } & $0-5 \mathrm{yll}$ & 4 \\
\hline & 6-10 yıl & \\
\hline & 11-15 yıl & 5 \\
\hline & $16-20$ yıl & 1 \\
\hline & 21-25 yıl & 3 \\
\hline
\end{tabular}




\section{Verilerin Toplanması}

Çalışmanın amacına uygun olarak veri toplamak için araştırma konusunda derinlemesine bilgi edinmeyi sağlayan (Büyüköztürk vd., 2010) ve araştırmanının amacı çerçevesinde yarı yapılandııııış görüşme formu hazırlanmıştır. Form, 5 sorudan oluşturulmuş ve Sosyal Bilgiler öğretmenlerine 2018 Sosyal Bilgiler dersi öğretim programında (SBÖP) yer alan kazanımların yeterliği, Sosyal Bilgiler öğretmenlerinin kullandıkları yöntem, yaşadıkları sorunlar ve çözüm önerileri ve öğretmenlerin öz yeterlik düzeylerine dair sorular sorulmuştur.

Görüşme formu ile ilgili 2 faklı Sosyal Bilgiler eğitimcisinden uzman görüşleri alınmıştır. Ayrıca ifadelerin açık ve anlaşılırlığı ile görüşülecek gruba uygunluğunu tespit etmek için Kars Milli Eğitim Müdürlüğü’nden gerekli izinlerde alındıktan sonra pilot çalışma yapılmıştır. Pilot çalışmaya 2018-2019 eğitim-öğretim yılında Kars ilinde bulunan iki ortaokulda görev yapmakta olan 3 Sosyal Bilgiler öğretmeni katılmıştır. Pilot çalışmaya katılan öğretmenlere 5 sorudan oluşan taslak haldeki yarı yapılandırılmış görüşme formunda yer alan sorular sorulmuştur. Öğretmenlerden alınan dönütler sonrasında herhangi bir değişiklik yapılmadan yarı yapılandırılmış görüşme formu uygulamaya konulmuştur. Kars il merkezinde bulunan 9 ortaokulda görev yapan toplam 13 Sosyal Bilgiler öğretmeniyle çalışmaya başlanmıştır. Öğretmenlerle yüz yüze görüşme yapılarak çalışmanın nasıl yapılacağı hakkında bilgi verilmiştir. Öğretmenlerle öğretmenler odası ya da müdür yardımcısının odasında 10-15 dakika süren görüşmeler yapılmış ve öğretmenden yazılı olarak görüşme sorularının cevapları alınmıştır.

\section{Verilerin Analizi}

Araştırmada katııımcılarla yapılan görüşmelerden elde edilen verilerin dökümü yapılmış ve veriler analiz edilmiştir. Verilerin analizinde katılımcıların görüşlerinin çarpııı bir biçimde yansıtılması amacıyla, doğrudan alıntılara sıklıkla yer verilen betimsel analiz yöntemi kullanılmışır (Yıldırım \& Simşek, 2008). Veri analizinde verilerin kodlanması, kodlanan verilerde temaların belirlenmesi, kodların ve temaların düzenlenmesi ve bulguların tanımlanması ve yorumlanması (Yıldııı ve Şimşek, 2008) olmak üzere 4 aşama izlenmiştir. Analiz sürecinde öncelikli olarak, görüşme formların çözümlenmesi yapılmıştır. Katılımcıların görüşlerinin analizinde, ifadelerin benzerliğine göre gruplamalar yapılmış ve ifadeler tablolara aktarılarak frekanslarla birlikte sunulmuştur. Araştırma da elde edilen kodlar ve bulgular öğretmenlerin görüşme formundaki sorulara verdiği yanıtlardan doğrudan alıntılar yapılarak desteklenmiştir. Öğretmen isimleri kullanılmamış ve öğretmenler Ö1, Ö2, Ö3...Ö13 olarak kodlanmıştır.

Elde edilen bulguların gerçeği yansıtabilmesi geçerlik, bu bulguların tutarlılı̆ı ve tekrar edilebilirliği ise güvenirlik olarak tanımlanmaktadır (Yıldırım ve Şimşek, 2011). Bu araştırmanın geçerlilik ve güvenirliliğini sağlamak için; a) içerik analizinde her bir görüş formunu araştırmacı ve alan uzmanı bir kişi ayrı ayrı inceleyerek elde edilen analiz birimlerini karşılaştırmış ve farklı ifadelerin yer aldığı durumlarda söz konusu veri toplama aracı birlikte incelenerek ilgili analiz birimi yeniden düzenlenmiş, b) elde edilen veriler analiz edildikten sonra katııımıların da onayını almak için öğretmenlerin görüşlerine sunulmuş, c) birden fazla kodlayıcı tarafından kodlanan veri setinin benzerlik oranları araştırmacıların bireysel etkisinden arındırıması ve güvenirliliği belirlemek açısından önemlidir (Fidan ve Öztürk, 2015; Bozan ve Ekinci, 2020). Miles ve Huberman (1994) tarafından geliştirilen formül [(Güvenirlik= Görüş birliği/ (Görüş birliği + Görüş ayrılığı)] kullanılarak güvenirlik katsayısı hesaplanmıştır. Araştırmanın güvenirliği \%86 olarak belirlenmiş̧ir. Yıldırım ve Şimşek'e (2011) göre, güvenirlik hesaplamasındaki uyuşum yüzdesi \%70 olduğunda güvenirlik yüzdesine ulaşılmış kabul edilir.

\section{BULGULAR}

Bu bölümde ortaokulda görev yapan Sosyal Bilgiler öğretmenlerinin tarih konularının öğretiminde yaşadıkları sorunlara yönelik yapılan görüşmelerden elde edilen verilerin analiz edilmesiyle ortaya çıkan bulgulara yer verilmiştir.

\section{Sosyal Bilgiler Öğretmenlerinin Tarih Konularının Öğretimi Açısından 2018 SBÖP’de Yer Alan Kazanımların Yeterliğine Yönelik Görüşleri}

Sosyal Bilgiler öğretmenlerine tarih konularının öğretimi açııından 2018 SBÖP'de yer alan kazanımları yeterli görüp görmedikleri sorulmuştur. Sosyal Bilgiler öğretmenlerinin görüşlerinden hareketle elde edilen tabloya ve öğretmen görüşlerinden alıntılara yer verilmiştir.

Tablo 2. 2018 SBÖP'de yer alan kazanımların yeterliği

\begin{tabular}{ll}
\hline 2018 SBÖP'de yer alan kazanımların yeterliği & $f$ \\
\hline Yetersiz & 11 \\
(Ö1, Ö2, Ö3, Ö4, Ö5, Ö6, Ö7, Ö8, Ö9, Ö10, Ö13) & 11 \\
Yeterli & \\
(Ö11, Ö12) & 2 \\
\hline
\end{tabular}

Yukarıda 2018 SBÖP'de yer alan kazanımların yeterliğine yönelik Sosyal Bilgiler öğretmenlerinin görüşlerini gösteren tabloya yer verilmiştir. Tablo 2'e göre Sosyal Bilgiler öğretmenlerinin çoğu, SBÖP'deki tarih konuları ile ilgili kazanımları yeterli görmediklerini, programda ders saatinin artırılması gerektiğini ifade ederken bazı öğretmenlerde kazanımların azaltılması gerektiğini belirtmişlerdir. Aşağıda Sosyal Bilgiler öğretmenlerinin görüşlerinden örneklere yer verilmiştir: 
"Hayır, bulmuyorum, iki kişinin başından geçenlerin kitaplarda hikayeleştirilmesi çok doğru değil, hikaye verilip soruları bilgi üzerinden sormaları ayrıca çelişki..." (Ö1)

"Zaman problemi ve derslerdeki kazanımların yoğun olması nedeniyle yeterli görmüyorum." (Ö3)

"Ders saatinin az olması konular fazla olunca sıkıntılar yaşıyoruz. Osmanlı tarihi, gerileme, duraklama, siyasi olaylara yer verilmemiş." (Ö5)

"Evet yeterli görüyorum. Çünkü programda her şey açıkça belirtilmiştir."(Ö11)

\section{Tarih Konularının Öğretiminde Kullandıkları Yönteme Yönelik Sosyal Bilgiler Öğretmenlerinin Görüşleri}

Sosyal Bilgiler öğretmenlerine tarih konularının öğretiminde kullandıkları yöntemlerin neler olduğuna dair sorular sorulmuştur. Sosyal Bilgiler öğretmenlerinin görüşlerinden hareketle elde edilen tabloya ve öğretmen görüşlerinden alıntılara yer verilmiştir.

Tablo 3. Tarih konularının öğretiminde öğretmenlerin kullandıkları yöntem

\begin{tabular}{l}
\hline Kullanılan yöntem \\
\hline Soru-cevap \\
(Ö1, Ö2, Ö3, Ö6, Ö7, Ö8, Ö9, Ö11, Ö12, Ö13) \\
Düz anlatım \\
(Ö2, Ö6, Ö7, Ö9, Ö11, Ö12, Ö13) \\
Drama \\
(Ö4, Ö6, Ö8, Ö10) \\
Yarışmalar \\
(Ö1, Ö3) \\
Tarihi olayları canlandırma \\
(Ö4, Ö9) \\
Tartışma \\
(Ö12, Ö13) \\
Diğeri* \\
(Ö4, Ö5, Ö8, Ö10, Ö11)
\end{tabular}

* Oyunlar, araştırma, tiyatro, beyin fırtınası, video izletme.

Yukarıda tarih konularının öğretiminde kullandıkları yönteme yönelik Sosyal Bilgiler öğretmenlerinin görüşlerini gösteren tabloya yer verilmiştir. Sosyal Bilgiler öğretmenlerinin çoğu derslerinde soru-cevap ve düz anlatım yöntemini kullandığını ifade ederken bazı öğretmenlerde drama tekniğini kullandığını ifade etmiştir. Tartışma yöntemini kullanan öğretmen sayısı ile yarışma ve tarihi olayları canlandırma tekniğini kullanan öğretmen sayılarının birbirine yakın olduğu da görülmektedir. Öğretmenlerin görüşlerinden bazı alıntılar aşağıda sunulmuştur:

"Vakit darlığı sebebiyle, düz anlatım, not tutturma ve soru-cevap şeklinde konuları işleyebiliyoruz." (Ö2)

"Konuların özelliğine göre değişiklik gösteriyor, akıllı tahta üzerinden oyunla konuların kavratılmasını daha çok yapıyorum."

(Ö5)

"Drama, tiyatro çünkü öğrenci işin içine katılıyor, hoşuna gidiyor. Tarihi kitaplarda öğrencinin hoşuna gidiyor." (Ö3)

\section{Sosyal Bilgiler Öğretmenlerinin Tarih Konularının Öğretimine Yönelik Öz Yeterlik Algıları}

Sosyal Bilgiler öğretmenlerinin tarih konularının öğretiminde kendilerini yeterli görüp görmediklerine dair sorular sorulmuştur. Alınan cevaplardan hareketle oluşturulan tabloya ve öğretmen görüşlerinden alıntılara yer verilmiştir.

Tablo 4. Tarih konularının öğretimine yönelik öğretmenlerin öz yeterlik algıları

\begin{tabular}{l}
\hline Öz yeterlik algıları \\
\hline Yeterli \\
(Ö2, Ö4, Ö5, Ö6, Ö7, Ö8, Ö9, Ö10, Ö11, Ö12, Ö13) \\
Yeterli değil \\
(Ö1, Ö3)
\end{tabular}

Yukarıda Sosyal Bilgiler öğretmenlerinin tarih konularının öğretimine yönelik öz yeterlik algılarına dair görüşlerini gösteren tabloda Sosyal Bilgiler öğretmenlerinin çoğu tarih konularının öğretiminde kendilerini yeterli gördüklerini çünkü derse hazırlıklı geldiklerini ve kendilerini geliştirdiklerini ifade etmişlerdir. Öğretmenlerden sadece 2'si tarih konularının öğretiminde kendilerini yeterli görmediklerini belirtmiştir. Aşağıda öğretmen görüşlerinden bazı alıntılara yer verilmiştir:

" Hayır yeterli görmüyorum. Çünkü lisans eğitimimizde tarih konularına yeterince yer verilmedi." (Ö1)

"Genellikle yeterli görüyorum. Çok iyi anlamaları için hazırlıklı geliyorum. Farkı yöntemler kullanıyorum." (Ö4)

"Evet, ama bilgi olarak biraz daha kendimi geliştirebilirim."(Ö8)

“Evet, çünkü güncel konuları takip etmenin yanı sıra alanımla ilgili kaynakları da takip ediyorum." (Ö13) 


\section{Sosyal Bilgiler Öğretmenlerinin Tarih Konularının Öğretiminde Yaşadıkları Sorunlar}

Sosyal Bilgiler öğretmenlerine yaşadıkları sorunların neler olduğu sorulmuştur. Sosyal Bilgiler öğretmenlerinin görüşlerinden hareketle elde edilen tabloya ve öğretmen görüşlerinden alıntılara yer verilmiştir.

Tablo 5. Tarih konularının öğretiminde yaşanılan sorunlar

\begin{tabular}{ll}
\hline Sorunlar & $f$ \\
\hline Öğrenci ön yargıları & 3 \\
(Ö1, Ö3, Ö11) & \\
Illginin azlığı & 2 \\
(Ö4, Ö5) & \\
Diğer* & \\
(Ö2, Ö4, Ö6, Ö7, Ö8, Ö9, Ö10, Ö12, Ö13) & 9
\end{tabular}

*Kazanımların fazla olması, ders saatinin az olması, günümüz şartlarına göre tarihi yorumlamaları, dersi ezber olarak görmeleri, öğrencinin tarih konularından sıkılması, ders kitabının yüzeysel olması, dersi sınıf geçme olarak görmeleri.

Yukarıda tarih konularının öğretiminde Sosyal Bilgiler öğretmenlerinin yaşadıkları sorunlara yönelik görüşlerini gösteren tabloya yer verilmiştir. Sosyal Bilgiler öğretmenleri, öğrencilerin tarih dersine karşı önyargılı olmaları ve tarih konularına yeteri kadar ilgi göstermemelerinden dolayı tarih konularını öğretmekte sıkıntı yaşadıklarını ifade etmişlerdir. Bunun yanı sıra ders saatinin yetersizliği, ders kitabının yüzeysel olması, öğrencinin dersi ezber olarak görmesi ve öğrencinin tarih konularından sıkılması, öğrencinin tarih dersinden sadece yüksek not almak istemesinden dolayı sorun yaşadıklarını belirtmişlerdir. Aşağıda öğretmen görüşlerinden bazı alıntılara yer verilmiştir:

"En çok yaşadığım sorun öğrencilerin tarihe ilgilerinin olmaması bu da tarih anlatırken beni biraz sıkıyor." (Ö5)

"Ders kitapları çok yüzeysel tarih öğretiminde yeterli değil."(Ö10)

"Öğrencilerin tarihe karşı ön yargılı olması sorun yaratıyor."(Ö11)

"Öğrenci sıkılıyor, tarih derslerini çok ezber buluyor."(Ö13)

\section{Sosyal Bilgiler Öğretmenlerinin Tarih Konularının Öğretiminde Yaşadıkları Sorunlara Yönelik Çözüm Önerileri}

Sosyal Bilgiler öğretmenlerinin tarih konularının öğretiminde yaşadıkları sorunlara yönelik çözüm önerileri ve öğretmen görüşleri tabloda gösterilmiş ve öğretmen görüşlerinden örneklere yer verilmiştir.

Tablo 6. Yaşanılan sorunlara yönelik çözüm önerileri

\begin{tabular}{lc}
\hline Öneriler & $f$ \\
\hline Ders saatinin artırılması & 2 \\
(Ö2, Ö3) & 2 \\
Öğrenci hazır bulunuşluğunun dikkate alınması & \\
(Ö3, Ö7) & 2 \\
Görselliğin kitaplarda daha fazla yer alması & \\
(Ö5, Ö13) & 8 \\
Diğeri* & \\
(Ö1, Ö2, Ö5, Ö8, Ö9, Ö10, Ö12, Ö13) & \\
\hline
\end{tabular}

* Programın içeriğinin düzenlenmesi, ders saati artırılmalı, kazanım azaltılmalı, tarih konuları eğlenceli hale getirilmeli, kitaplarda görselliğe daha fazla yer verilmeli, sayısal dersler başarı ölçütü olarak görülmemeli, öğrencilerin tarihi sevmesi sağlanmalı.

Yukarıda Sosyal Bilgiler öğretmenlerinin tarih konularının öğretiminde yaşadıkları sorunlara yönelik çözüm önerilerine dair görüşlerini gösteren tabloya yer verilmiştir. Tablo 6 incelendiğinde Sosyal Bilgiler öğretmenleri tarih konularının öğretiminde ders saatinin artırıması gerektiğini, ders içeriğinin öğrenci hazır bulunuşluğu dikkate alınarak hazırlanması gerektiği ve kitaplarda görsellere daha fazla yer verilmesi gerektiği belirtilmiştir. Aşağıda öğretmen görüşlerinden alıntılara bazı alıntılara yer verilmiştir:

"Ya ders saati artırılmalı ya da kazanımlar azaltılmalı..."(Ö2)

"Ders içerikleri öğrencilerin hazırbulunuşlukları dikkate alınarak hazırlanmalı ve ders saatleri artırılmalı." (Ö3)

"Tarih eğlenceli hale getirilmeli, görsellik kitaplarda daha çok olmalı, ilginç hikâyeler veya yaşanmış ilginç olaylar kitaplarda daha çok yer almalı." (Ö5)

\section{SONUÇ ve TARTIŞMA}

Sosyal Bilgiler öğretmenlerinin tarih konularının öğretimine yönelik görüşlerinin belirlenmesi amacıyla yapılan bu çalışmadan elde edilen bulgular incelendiğinde aşağıdaki sonuçlara ulaşılmıştır.

Araştırma bulgularından 2018 SBÖP'de yer alan kazanımların yeterliğine dair sonuçlara göre, tarih konularının öğretiminde Sosyal Bilgiler öğretmenleri, öğretim programını yeterli görmediklerini belirtmiştir. Çalışma bulgularından elde edilen sonuca göre öğretmenler, program hazırlanırken ya kazanımların azaltılmasını gerektiğini ya da ders saati dikkate alınarak yeniden 
düzenlenmesi gerektiğini ifade etmiştir. Yapılan farklı çalışmalarda benzer sonuçlara rastlamak mümkündür. Arslantaş (2006) ve Atbaşı (2007) tarafından yapılan iki farklı çalışmada SBÖP'nin çok kapsamlı olduğu ve öğrencilerin kavrama seviyelerinin üzerinde soyutluk taşıdığını vurgulamışlardır. Bunun yanı sıra uzun bir zamanı kapsayan tarih konularının öğretimine müfredatta yüzeysel bir şekilde yer verilmesi eleştirilmiştir (Yılmaz ve Kaya, 2011). Aynı zamanda programın yoğunluğundan dolayı bazı konulara çok ayrıntılı (Kuş ve Çelikkaya, 2010) yer verilirken bazı konulara ise yüzeysel (Topçu, 2016) yer verildiği Sosyal Bilgiler öğretmenleri tarafından eleştirilmiştir. Fakat Can (2019) yaptığı çalışmada 2018 SBÖP'de kazanımların yaklaşık \%25 oranında azaltıldığını ve programındaki kazanımların öğrenci seviyelerine daha uygun olarak düzenlendiğini belirtilmiştir.

Araştırmanın bulgularından elde edilen Sosyal Bilgiler öğretmenlerinin kullandıkları yönteme dair sonuçlara göre Sosyal Bilgiler öğretmenlerinin çoğu tarih konularını anlatırken çoğunlukla soru-cevap ve düz anlatım yöntemini kullandıklarını belirtirken, öğretmenlerden bazıları da drama tekniğini kullandıklarını dile getirmiştir. Yürüdür ve Coşkun Cımbız (2017) da yaptıkları çalışmada Sosyal Bilgiler öğretmenlerinin az da olsa drama tekniğini kullandıklarını ifade etmiştir. Tarihi olayları canlandırma tekniği, drama tekniği ve tartışma yöntemini kullanan öğretmen sayılarının birbirine yakın olduğu da görülmüştür. Yapılan çalışmadan elde edilen sonuçlara göre öğretmenlerin çoğu düz anlatım ve soru-cevap yöntemini kullandıkları söylenebilir (Has, 2019). Tarih öğretiminde çoğunlukla soru-cevap yönteminin kullanılması öğrencilerin yaratıcı düşünmelerine yararı olmadığı (Maimun ve Roslan, 2005'dan akt. Sadık Yılmaz, 2017; Chua, 2006) ifade edilmiştir. Benzer şekilde bazı çalışmalarda da öğretmenlerin gözlem gezisi ve tarihsel empati tekniği gibi yapılandırmacı yaklaşıma dayalı öğretim tekniklerini sürenin yetersiz olması (Akgül, 2006; Çelikkaya ve Kuş, 2009; Gönenç ve Açıkalın, 2017) nedeniyle kullanamadıklarını belirtmişlerdir. Dahası ders saatinin yetersiz olması sebebiyle konuların üst üste yığılarak basit ve yüzeysel bir hale getirildiği (Topçu, 2016, Yılmaz ve Tepebaş, 2011) de yapılan çalışmalarda görülmektedir. Polat'a (2006) göre Sosyal Bilgiler dersinde tarih konuları öğretilirken tarihi olayların ya da karakterlerin canlandırılması en sık kullanılan tekniklerden biridir. Bu teknikle öğrenci tarihi karakterlerin yerine kendini koyup olayları kendi bakış açısıyla anlatabilmektedir. Böylece tarih öğretiminde yeni yaklaşımlar ve öğretim teknikleriyle (Subrt, 2013) öğrencinin hem derse karşı ilgisi artacak, hem de kendi tecrübelerinden faydalanarak öğrenme ortamı oluşturmasına zemin hazırlayacaktır. Yapılan çalışmalardan da anlaşıldığı üzere Sosyal Bilgiler ders saatinin artırılmasıyla öğretmen farklı yöntem/teknik kullanılabilecektir. Böylece öğrenci derste daha aktif olacak ve tarih konularına karşı önyargı oluşmayabilecektir.

Araştırma bulgularından elde edilen sonuçlara göre Sosyal Bilgiler öğretmenleri tarih konularının öğretiminde kendilerini yeterli gördüklerini çünkü lisans eğitimleri boyunca iyi bir eğitim aldıklarını ifade etmiştir. Topçu (2016) da yaptığı çalışmada benzer sonuçlara ulaşmış ve lisans eğitimleri boyunca verilen akademik bilginin tarih konularının öğretiminde yeterli olduğunu belirtmiştir. Fakat yapılan benzer çalışmalarda öğretmenler, eğitim aldıkları okullarda meslekî yaşamda ihtiyaç duyacakları eğitimi alamadıklarını, mesleğe başladıktan sonra kendilerini geliştirdiklerini dile getirmiştir (Gönenç ve Açıkalın, 2017; Tahiroğlu, 2006; Yılmaz ve Tepebaş, 2011).

Araştırma bulgularından elde edilen sonuca göre göre Sosyal Bilgiler öğretmenleri tarih konularını öğretirken sıkıntı yaşadıklarını belirtmişlerdir. Sosyal Bilgiler öğretmenleri, tarih konularını öğretirken tarih dersine karşı öğrencilerin önyargılı olmalarını ve tarih konularına yeteri kadar ilgi göstermemelerini sıkıntı yaşamalarında gerekçe olarak göstermişlerdir. Bunun yanı sıra ders saatinin yetersizliği, ders kitabının yüzeysel olması, öğrencinin dersi ezber olarak görmesi, öğrencilerin tarih konularından sıkılması ve öğrencinin tarih dersinden sadece yüksek not almak istemesinden dolayı sorun yaşadıklarını belirtmişlerdir. Öğrencilerin çeşitli nedenlerden dolayı tarih konularına yeteri kadar ilgi göstermediği anlaşılmıştır. Benzer çalışmalarda öğrencilerin tarih dersini sıkıcı olarak görmeleri, derse olan ilginin az olması (Bal, 2011; Yıldız, 2003; Doğaner, 2005), öğrencilerin dikkatlerini derse çekme ve motivasyonlarını sağlamada güçlük yaşamalarına neden olmuştur (Ağır, 2003; Range, 2011'dan akt. illhan ve Oruç, 2019). Gönenç ve Açıkalın (2017) yaptığı çalışmada öğretmenler SBÖP'de konuların fazla olması, tarih konularında kronolojik sıraya dikkat edilmemesi ve bölgesel farklılıklar dikkate alınmadan hazırlanan bir program olması sebebiyle hem öğretmenler hem öğrenciler için sorun oluşturduğu belirtilmiştir. Ayrıca bu çalışmada Sosyal Bilgiler ders kitaplarında bazı öğrenme alanlarında öğretilmesi gereken temel bilgilere yer vermezken, bazı öğrenme alanlarında ise gereksiz ayrıntıya yer verildiği öğretmenler tarafından eleştirilen başka bir husus olmuştur. Gönenç ve Açıkalın (2017) yukarıda belirtilen ifadeye örnek olarak, 7. sınıf Türk Tarihinde Yolculuk ünitesinde yer alan Osmanlı Devleti ile alakalı kısma yüzeysel olarak değinildiğini ve bu ünitede yer alan konuların birbiriyle bağlantılı olmadığını dile getirirken aynı şekilde 6. sınıf İpek Yolu’nda Türkler ünitesinde yer alan bazı konularda fazla ayrıntıya yer verilip öğrenciyi sıkacak duruma getirdiğini ifade etmiştir. Benzer çalışmalarda öğretmenler genel olarak görselliğe, kitabın içeriğine, ihtiva ettiği bilgiye, konuyla alakalı verilen örneklere nicelik ve nitelik açısından olumsuz düşüncelere sahip olduklarını belirtmiştir (Arslantaş, 2006; Kuş ve Çelikkaya, 2010).

Araştırma bulgularından elde edilen sonuçlara göre Sosyal Bilgiler öğretmenleri tarih konularının öğretiminde ders saatinin artırılması gerektiğini, öğrenci hazır bulunuşluğunun dikkate alınmasını ve kitaplarda görsellere daha fazla yer verilmesi gerektiği ifade etmiştir. Benzer çalışmalar da Sosyal Bilgiler dersinde tarih konularının verimli bir şekilde öğretilebilmesi için derse ayrılan sürenin artırıması (Akdağ, 2008; Bal, 2011; Bayram, 2012; Sadık Yılmaz, 2017) gerektiği belirtilmiştir. Buna ek olarak öğrencilerin derse katılımını sağlamak, derse karşı öğrencide merak ve ilgi uyandırmak ve öğrencileri derse motive edecek bir öğrenme ortamı oluşturulması gerektiği dile getirilmiştir (Gönenç ve Açıkalın, 2017). Aynı zamanda öğrencinin merkeze alınarak etkinlikler yoluyla (Bal, 2011) farklı yöntem/teknik kullanarak tarih konularının öğretimi öğrencilerin farklı zeka türleri etkili bir şekilde kullanmasına neden olacaktır.

\section{ÖNERILER}


Araştırmada ortaya çıkan öğretmenlerin bazılarının soru-cevap ve düz anlatıma vurgu yaptıkları sonucundan hareketle Sosyal Bilgiler öğretmenlerine Sosyal Bilgiler dersinde tarih konularının öğretiminde düz anlatım ya da soru-cevap yönteminden ziyade öğrenciyi aktif hale getirecek yöntem ve tekniklere yer vermeleri önerilmektedir.

Sosyal Bilgiler öğretmenleri Sosyal Bilgiler dersinde tarih konularının öğretiminde kullandıkları yöntem ve tekniklerde öğrencilerin bireysel farklılıklarını dikkate alacak şekilde planlamalıdır.

Sosyal Bilgiler öğretmenlerden alınan cevaplardan hareketle MEB Sosyal Bilgiler öğretim programı yeniden gözden geçirerek kazanımlarla ilgili daha fazla açıklamaya yer vermesi önerilmektedir.

\section{KAYNAKÇA}

Ağır, Ö. (2003). ilköğretim ikinci kademe Sosyal Bilgiler dersinin öğretiminde karşılaşılan sorunlar (Yayınlanmamış yüksek lisans tezi). Atatürk Üniversitesi, Sosyal Bilimler Enstitüsü, Erzurum.

Akbaba, B. (2008). Atatürk ilkeleri ve inkılâp tarihi dersinin öğretiminde karşılaşılan sorunlar (Gazi Üniversitesi örneği). Akademik Bakış, 1(2), 177197.

Akdağ, H. (2008). ilköğretim 6. ve 7. sınıf Sosyal Bilgiler öğretim programının öğretmen ve öğrenci açısından uygulama dönütleri (Konya ili örneği) (Yayınlanmamış doktora tezi). Gazi Üniversitesi, Eğitim Bilimleri Enstitüsü, Ankara.

Akgül, N. i. (2006). Sınıf öğretmenlerinin Sosyal Bilgiler öğretiminde kullandıkları yöntemler ve karşılaşılan sorunlar (Niğde ili örneği) (Yayınlanmamış yüksek lisans tezi). Niğde Üniversitesi, Sosyal Bilimler Enstitüsü, Niğde.

Arslantaş, S. (2006). 6. ve 7. sınıf Sosyal Bilgiler ders program uygulamalarında karşılaşılan sorunların öğretmen görüşleri açısından incelenmesi (Malatya ili örneği) (Yayınlanmamış yüksek lisans tezi). Fırat Üniversitesi, Sosyal Bilimler Enstitüsü. Elazı̆̆.

Atbaşı, C. (2007). Illköğretim II. kademe (6. ve 7. sınıfta) Sosyal Bilgiler dersinin öğretimi ve öğretiminde yaşanan güçlükler (Aksaray örneği) (Yayınlanmamış yüksek lisans tezi). Selçuk Üniversitesi, Sosyal Bilimler Enstitüsü, Konya.

Avcı Akçalı, A. ve Aslan, E. (2016). Tarih öğretiminde yerel tarih kullanımının akademik başarıya ve tarihsel düşünme becerilerine etkisi. Gazi Üniversitesi Gazi Eğitim Fakültesi Dergisi, 36(2), 375-397.

Bal, M. S. (2011). Türkiye'de tarih öğretiminin sorunları ve çözüm yolları konusunda öğretmen adayı ve öğretmen görüşlerinin karşılaştırılması. Mustafa Kemal Üniversitesi Sosyal Bilimler Enstitüsü Dergisi, 8(15), 371-387.

Bayram, H. (2012). Sosyal Bilgiler dersinde alternatif ölçme değerlendirme yöntemi olarak portfolyo (öğrenci ürün) dosyası, performans ve proje görevi uygulamasına ilişkin öğretmen görüşleri (Yayınlanmamış yüksek lisans tezi). Kilis 7 Aralık Üniversitesi, Sosyal Bilimler Enstitüsü, Kilis.

Bozan, S. ve Ekinci, A. (2020). Öğretmenlerin mesleklerinin ilk yıllarında sınıf yönetiminde yaşadıkları sorunlara ilişkin görüşlerinin değerlendirilmesi. Kastamonu Eğitim Fakültesi Dergisi, 28(1), 137-153.

Büyüköztürk, Ş., Kılıç Çakmakçı, E., Akgün, Ö.E., Karadeniz, Ş. ve Demirel, F. (2010). Bilimsel araştırma yöntemleri. (7. Baskı). Ankara: Pegem.

Can, B. (2019). 2005 ve 2018 Sosyal Bilgiler dersi öğretim programlarının incelenmesi (Yayınlanmamışüksek lisans tezi). Balıkesir Üniversitesi, Sosyal Bilimler Enstitüsü, Balıkesir.

Chua, K.H. (2006). The Development of patriotics values in the teaching and learning history form two: Comparation between four schools (Unpublished masters theses). Universiti Malaysia Sabah: Malaysia.

Çelikkaya, T. ve Kuş, Z. (2009). Sosyal Bilgiler öğretmenlerinin kullandıkları yöntem ve teknikler. Uludağ Üniversitesi Eğitim Fakültesi Dergisi, 22(2), 741-758.

Dilek, D. (2002). Tarih derslerinde öğrenme ve düşünce gelişimi. Ankara: Pegem.

Dinç E. (2006). Tarih eğitimcilerinin mevcut lise tarih müfredat programı ve tarih öğretiminin amaçları hakkındaki görüşleri. Ahi Evran Üniversitesi Kırşehir Eğitim Fakültesi Dergisi (KEFAD), 7(2), 263-276.

Doğaner, Y. (2005). Yükseköğrenimde Atatürk İlkeleri ve İnkılâp Tarihi dersinin öğretiminde karşılaşılan problemler ve yeni yaklaşımlar. Atatürk Araştırma Merkezi Dergisi, 21(62), 589-611.

Er, A. R. ve Bayındır, N. (2015). Sosyal Bilgiler dersi öğretmenlerinin tarih konularının öğretimine ilişkin öğretmen unsuru ile fiziki koşullar ve materyal hakkındaki görüşlerinin belirlenmesi. Uşak Üniversitesi Ĕgitim Araştırmaları Dergisi, 1(1), 88-103.

Erkuş, A. (2009). Davranış bilimleri için bilimsel araştırma süreci. Ankara: Seçkin.

Fidan, T., Öztürk, i. (2015). Perspectives and expectations of union member and non- union member teachers on teacher unions. Eğitim Bilimleri Araştırmaları Dergisi, 5(2), 191-220.

Gökalp, M. (2016). Öğretim ilke ve yöntemleri. Ankara: Pegem.

Gönenç, S. ve Açıkalın, M. (2017). Sosyal Bilgiler öğretmenlerinin Sosyal Bilgiler öğretiminde karşılaştıkları sorunlar ve bunlara getirdikleri çözüm önerileri. Trakya Üniversitesi Eğitim Fakültesi Dergisi, 7(1), 26-41.

Güngör, O. (2019). Sosyal Bilgiler ders kitaplarında (2017-2018 dönemi) Hitit tarihinin tarih öğretimi açııından değerlendirilmesi (Yayınlanmamış yüksek lisans tezi). Mehmet Akif Ersoy Üniversitesi Eğitim Bilimleri Enstitüsü, Burdur.

Has, S. (2019). Sını öğretmenlerinin Sosyal Bilgiler dersinde kullandıkları yöntem ve teknikler ile dersin öğretiminde karşılaştıkları sorunlar: Muş ili örneği. Atatürk Üniversitesi, Eğitim Bilimleri Enstitüsü, Erzurum.

İlhan, G. O. ve Oruç, Ş. (2019). Sosyal Bilgiler dersinde çizgi roman kullanımı: Teksas tarihi. Eğitim ve Bilim, 44(198), 327-341.

İslamoğlu, H. (2009). Sosyal bilimlerde araştırma yöntemleri. İstanbul: Beta.

Karabağ, G., (2011). Disiplinlerarası tarih çalışması. İçinde A. Şimşek (Ed.), Tarih Nasıl Yazılır? (s. 223-257). İstanbul: Tarihçi Kitapevi.

Kaymakcı, S. (2017). Türkiye'de tarih öğretiminin yönelimi üzerine bir değerlendirme. Kastamonu Eğitim Dergisi, 25(6), 2153-2172

Kuş, Z. ve Çelikkaya, T. (2010). Sosyal Bilgiler öğretimi için Sosyal Bilgiler öğretmenlerinin beklentileri. Yüzüncü Yıl Üniversitesi Eğitim Fakültesi Dergisi, 7(2), 69-91.

Maimun, A. ve Roslan H.A. (2005). Teaching methodology for İslamic knowledge in Brunei Darulsalam Universiti Kebangsaan Malaysia: Jurnal Pendidikan, 30, 141-150. 
Miles, M. B., ve Huberman, A. M. (1994). Qualitative data analysis: An expanded sourcebook (2 nd ed). CA: Sage Publication.

Milli Eğitim Bakanlığı, (2018). Sosyal bilgiler dersi programı. mufredat.meb.gov.tr

Öner, G. (2015). Sosyal Bilgiler öğretmenlerinin 'okul dışı tarih öğretimine ilişkin görüşlerinin incelenmesi. Turkish History Education Journal, 4(1), 89-121.

Pekuslu, M. N. (2019). 5. Sınıf Sosyal Bilgiler dersi öğretim programına ilişkin Sosyal Bilgiler öğretmenlerinin görüşleri (Isparta ili örneği) (Yayınlanmamış yüksek lisans tezi). Pamukkale Üniversitesi, Eğitim Bilimleri Enstitüsü, Denizli.

Polat, F. (2006). Illköğretim 7. sınıf Sosyal Bilgiler öğretiminde öğretmenlerin kullandıkları yöntemler ve karşılaştıkları sorunlar (Afyonkarahisar örneği) (Yayımlanmamış yüksek lisans tezi). Gazi Üniversitesi, Ankara.

Robson, C. (2015). Bilimsel araştırma yöntemleri gerçek dünya araştırması (Çev. Ş. Çınkır ve N. Demirkasımoğlu). Ankara: Anı.

Sadık Yılmaz, H. (2017). Ortaöğretim tarih öğretiminde öğretmenlerin karşılaştıkları sorunlar ve çözüm önerileri (Siirt Örneği)(Yayınlamamış yüksek lisans tezi). Çanakkale Onsekiz Mart üniversitesi, Çanakkale.

Sönmez, V. ve Alacapınar, F. (2014). Örneklendirilmiş bilimsel araştırma yöntemleri. (3. Baskı) Ankara: Anı.

Subrt, J. (2013). Historical Consciousness and the teaching of history in the Czech Republic. Studia Edukacyjne, 24, 195-223.

Tahiroğlu, M. (2006). ilköğretim okulları ikinci kademesinde Sosyal Bilgiler dersi öğretmenlerinin, Sosyal Bilgiler dersi öğretiminde karşılaştıkları güçlükler (Yayınlanmamış yüksek lisans tezi). Selçuk Üniversitesi, Konya.

Tonga, D. (2017). Sosyal Bilgiler eğitiminde karşılaşılan sorunlar üzerine bir değerlendirme. Türk İlam Dünyası Sosyal Araştırmalar Dergisi, 4(12), 187-201.

Topçu, E. (2016). Ortaokulda tarih eğitimi yapısal sorunlar ve çözüm önerileri. Türkiye Bilimsel Araştırmalar Dergisi, 1(1), 22-35.

Turna, Ö. ve Bolat, M. (2015). Eğitimde disiplinlerarası yaklaşımın kullanıldığı tezlerin analizi. Ondokuz Mayıs Üniversitesi Ĕgitim Fakültesi Dergisi, 34(1), 35-55.

Ulusoy, K. (2009). Sosyal Bilgiler öğretiminde yeni yaklaşımlar 1. Ankara: Pegem.

Ünal, Ç. ve Başaran, Z. (2010). Yeni program çerçevesinde Sosyal Bilgiler öğretmenlerinin sorunları (Erzurum). Milli Eğitim, 186, $291-309$.

Yıldırım, A. ve Şimşek H. (2011). Sosyal bilimlerde nitel araştırma yöntemleri. Ankara: Seçkin.

Yıldırım, A. ve Şimşek, H. (2008). Sosyal bilimlerde nitel araştırma yöntemleri. Ankara: Seçkin.

Yıldız, Ö. (2002). Türkiye'de tarih öğretiminde işbirlikli öğrenme yönteminin uygulanışı (Yayınlanmamış yüksek lisans tezi). Dokuz Eylül Üniversitesi, İzmir.

Yıldız, Ö. (2003). Türkiye'de tarih öğretiminin sorunları ve çağdaş çözüm önerileri. Erciyes Üniversitesi Sosyal Bilimler Enstitüsü Dergisi, 1(15) , 181-190.

Yıldızlar, M. (2014). Öğretim ilke ve yöntemleri. Ankara: Pegem.

Yılmaz, K. ve Kaya, M. (2011). Sosyal Bilgiler öğretmenlerinin tarih algısı ve tarih öğretimine pedagojik yaklaşımları. Dicle Üniversitesi Sosyal Bilimler Enstitüsü Dergisi, 6, 73-94.

Yılmaz, K. ve Tepebaş, F. (2011). illköğretim düzeyinde Sosyal Bilgiler eğitiminde karşılaşılan sorunlar: Mesleğine yeni başlayan Sosyal Bilgiler öğretmenlerinin görüşleri, Çankırı Karatekin Üniversitesi Sosyal Bilimler Enstitüsü Dergisi, 2(1), 157-177.

Yürüdür, E. ve Cımbız, T. C. (2017). Sosyal Bilgiler öğretmenlerinin yapılandırmacı yaklaşıma dayalı sınıf içi uygulamalarına yönelik görüşleri. Erzincan Üniversitesi Eğitim Fakültesi Dergisi, 19(3), 276-300. 